Article

\title{
Introducing the Concept of Organic Products to the Primary School Curriculum
}

\author{
Aikaterini D. Kosta *(D) and Konstantinos P. Tsagarakis( \\ Business and Environmental Technology Economics Laboratory (BETECO), Department of Environmental \\ Engineering, Democritus University of Thrace, 67100 Xanthi, Greece \\ * Correspondence: katerkosta@gmail.com; Tel.: +30-25410-79397
}

Received: 1 May 2019; Accepted: 19 June 2019; Published: 28 June 2019

\begin{abstract}
Awareness for organic products is low for young people. This paper sheds light on primary school pupils' knowledge about organic products before and after a dedicated information session and analysis of their preferences for logos of organic products. Furthermore, we explore the intervention impact per grade. The analysis of 724 pupils' responses, age ranged from 6 to 12 years, reveals gap in their knowledge about organic products. This intervention seems to affect more pupils older than 10 years. The majority of them would prefer the previously established organic logo with optional use to certify organic goods. Finally, the evaluation of logo drawings created by the pupils shows their slight preference for green colours and rounded shape. Our intervention can assist better design school curriculums regarding environmental related issues.
\end{abstract}

Keywords: organic product; logo; pupils; primary school

\section{Introduction}

In recent years, EU organic food production has increased [1] as a result of consumers' understanding that the organically produced goods are healthier than the conventionally produced ones [2]. "Organic Farming" appeared as a term in 1940 and it describes the use of organic materials in farming [2] based on ecological systems and limited use of external inputs, such as pesticides and chemicals [3]. In 1960, organic farming appeared in Germany, Switzerland and the United Kingdom [4]. According to Eurostat (2016), there are 30.7 billion European consumers of organic products. The development of organic market sales has increased significantly by $47.7 \%$ since 2012 [5] and is in line with high demand [6-9], while the profile of its consumers has been extensively studied [2,10]. What people know about organic product standards is limited [11] as in the case of organic food [6]. Consumers give subjective interpretations of what is "organic" [4,7,12]. Regardless of the development level of a country, there is a lack of knowledge concerning organic food. For instance, Zepeda et al. [13] showed that African Americans did not purchase organic products because many of them were unfamiliar with the products; while a recent study in Tennessee showed that $13.6 \%$ of consumers know nothing about organic food [9].

Consumers' perception of organic labelling systems tends to be mostly subjective and thus lacks objective knowledge [14]. Zander et al. [15] suggest that the organic logo diffusion is equally important with consumers' knowledge and awareness for reinforcing successful labelling. This is also supported by Fotopoulos and Krystallis [16] who found some confusion among Greek consumers, as one-third of surveyed respondents reported being aware of existing organic labels but some of them did not recognize the national logo of organic products.

Consumers recognize many organic products by their certification logos or labels associated with their production. In fact, some studies $[17,18]$ have found a positive relationship between consumer purchasing decisions and labelling of organic products. Consumers generally perceive an organic label as a guarantee that the product is organic [19]. Consumers' attitudes towards organic products and 
recognition of organic logos are critical to the organic food industry [7]. Janssen and Hamm [8] showed that consumers only trust quality products with an "organic" label. Organic product market penetration is more efficient when it addresses consumers who are not familiar with organic products [16]. It is also important to note that knowledge and awareness of organic products do not necessarily translate into a direct market share, due to barriers that could prevent this knowledge and perception from increasing demand [20,21]. Janssen [22] showed that while $20 \%$ of a survey respondents report a positive attitude towards organic food, only $3 \%$ actually buy it.

Children and adolescents are the future consumers, and previous research indicated that they are able to significantly influence their parents' habits and practices [23-25]. Young individuals are more willing to eat and pay for quality food products compared to older ones [3]. Indeed, consumers accept organic food less easily, especially when quality attributes cannot be assessed by their appearance [26]. Consumers cannot verify by themselves any product quality related to the method of production [7]. A producers' logo certified by authorities can identify the production technology [5]. Riefer and Hamm [27] report that young consumers make up an important target group of the organic food market but more research on their knowledge and attitudes towards organic food is necessary [28]. McReynolds et al. [6] found that the majority of students have received no formal education on organic food in the classroom and are unaware of its importance and benefits. On the other hand, Dahm et al. [29] report that younger people are more likely to properly define "organic", while McReynolds et al. [6] showed that age has no impact on such knowledge.

Nevertheless, as a higher level of education corresponds to more knowledge [30,31], pupils with a higher level of education or better school performance were more aware of the value of organic products. It is generally accepted that as consumers become more aware and educated regarding health and well-being they are more likely to consume healthier food [3,32].

Environmental education still has no specific guidelines as to the best age to introduce this information [29]. Wijne et al. [33] report that younger children are most affected by information. According to their research, $45 \%$ of children 11-12 years old changed their mind after receiving information on organic food, while only $18 \%$ of those age $13-14$ years and $13 \%$ of those age $15-16$ years did.

Schools in general can affect pupils' knowledge, attitudes and behaviors [34] and particularly, environmental programs can raise awareness and help in the adoption of positive attitudes and behaviors towards the environment $[35,36]$. The teachers play a catalytic role in shaping and disseminating environmental knowledge, which leads to the progress of education [37]. According to Payne [38] "The 'right' environmental knowledge is a partial starting point in creating the appropriate attitudes and values especially in environmental education". Martinis et al. [39] reported that environmental education has a great effect on raising knowledge and awareness of the environment.

To sum up, education can obviously play an important role in organic food awareness and consumption [40]. In the Greek primary school curriculum and schoolbooks, organic farming or food are not mentioned anywhere, although lectures on diet-related attitudes and habits are presented in the classrooms. The aim of this paper is to shed light on how school interventions under the environmental education framework can be effective in increasing organic product awareness. Another objective of this survey is to investigate the effectiveness of the organic logos employed so far based on the degree of preference as well as to elicit further insights from the pupils' preferences in colors and shapes for possible comparisons with the existing logos or even to explore new elements for logo design. Raising awareness programs should be designed in line with the education system and the school curriculum [41]. For this reason, we designed a research project in line with the Greek primary education system and more specifically within the environmental education curriculum. Environmental education first appeared in Greece in the early 1980s and it was officially introduced in schools by law in 1990. It was initially implemented after school hours and pupils' participation was voluntary (Law 1892/90). Following some legislation updates, it was then included in the Cross-Thematic Curriculum Framework [42]. The basic method applied in Greece is experimental education, with an emphasis on learning by acting and doing [43,44]. 


\section{Methodology}

In order to elicit pupils' knowledge beliefs and preferences for organic products and logos as well as for the existing certified logos, we designed a questionnaire with structured and semi-structured questions. The questionnaire consisted of three parts and an information session, with a completion time of around 45 minutes.

The first part was designed to access the pupil awareness. To evaluate the effect of our intervention, at first we asked pupils to report by writing a definition of "organic products" (before applying the information session), then a video (of 10 min duration) was projected (excerpt of child-information state TV broadcast), which provided information outlining what organic products are, how they are produced and in what ways they differ to conventionally produced products [45]. Afterwards, pupils were again asked to provide a definition of "organic products". EU defines "organic products" as those products using "an overall system of farm management and food production that combines best environment practices, a higher level of biodiversity and the preservation of natural resources" [11]. Based on this and on pupils' responses, we created an ordinal "Knowledge" variable as follows: Know nothing, wrong definition with some correct elements, correct definition with some wrong elements and correct definition about organic products. This helped in the assessment of the effectiveness of information provided according to the pupils' school level (and age).

We also explored the origin of their knowledge by giving five possible response options: Family, school, television/press, Web, don't remember, as well as the choice of "other". We gave them the option of selecting one or more responses. Then, pupils were asked to state if they themselves had used organic products. Those responding positively were given the option of selecting which category of the product they have used; detergents, cosmetics, food or clothing. Next, pupils' intention to use organic products was requested.

The second part included questions towards obtaining socio-economic information such as gender, grade, whether they had older brothers or sisters, the profession of their parents and their place of residence in order to investigate whether such variables affect the pupils' initial knowledge about organic products. In the third part, pupils were asked to draw a logo. They were provided a blank A4 sheet of paper and a brand new set of pencils with the twelve basic colours of a known brand. The teachers advised them to let their imagination run free and design a logo of how organic products should be represented.

Finally, three logos were presented to each pupil. The first was the official European (hereafter abbreviated Logo_1). This logo (Figure 1a) consists of a white fond leaf made of the EU stars on a green background [46]. The European Commission for the certification of organic products had proposed the other two logos earlier, but their use was not mandatory [47]. Both of them had rounded shape and their depiction included the EU (flag) stars. The logo (Figure 1b) of 2002 (hereafter abbreviated Logo_2) consisted of the EU flag with an ear of wheat in the center and the inscription "Organic Farming" in the official language of each EU member-state [46,48]. The logo (Figure 1c) of 2008 (hereafter abbreviated Logo_3) was much more simple, as, apart from the stars, it only contained the prefix "bio" in the shade of blue and green. However, that logo was withdrawn due to a dispute with a food chain $[49,50]$. At this point each student had to select one of the three logos he/she would consider the most appropriate for the European certification of organic products; which is the logo that he wished to be displayed on product packaging, reflecting both the organic certification and the European connotation thereof. To prevent order effects, three different versions were created in which each of the logos was shown in a different placement (changing logos' placement). In this way, each logo was equally placed, at the beginning, in the middle and at the end of the card (see Figure 1 one of those versions). Only one of the three versions was presented to each pupil. 


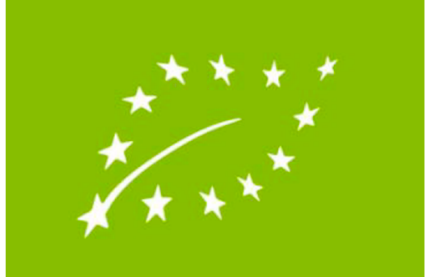

(a)

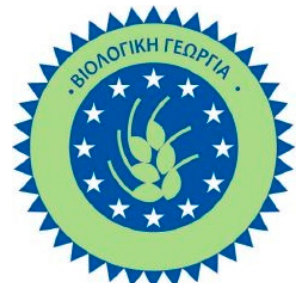

(b)

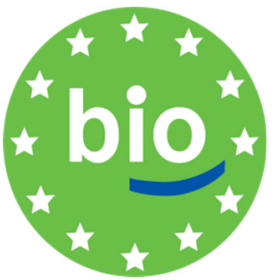

(c)

Figure 1. Organic logos: (a) the official European (Logo_1); (b) the first voluntary EU (Greek version-Logo_2); (c) the second EU voluntary. This is the first version of the card presented to pupils for selecting the desired logo.

The implementation of environmental programs in Greece is conducted using the project method, which Kilpatrick [51] called "philosophy" of education. According to Matsagouras [49], the project method is defined as "each organized learning activity with collective form developed in a context of free choice, based on a predefined plan and aimed at the exploration, organization and management of knowledge, materials, values and actions that directly interest the pupils as individuals or as members of social groups". In this context, a project aims at "the enhancement of intrinsic motivation, independent thinking, self-esteem and social responsibility" [52]. The investigation of specific teaching methods and strategies is essential for the development of environmental education. This can provide a detailed insight into the personal values of pupils, but can also cultivate new values, which enhance the adoption of environmentally friendly behaviors [53].

A focus group of eleven primary school teachers with over ten years experience in teaching discussed the optimal age for this intervention on the basis of the survey results, which was audiotaped and then transcribed. The subject of the discussion was related to the optimal age for the implementation of environmental programs in primary education, based on the study's findings.

The methodology approach and our findings might be a valuable tool and contribute to education policy improvements (Figure 2).

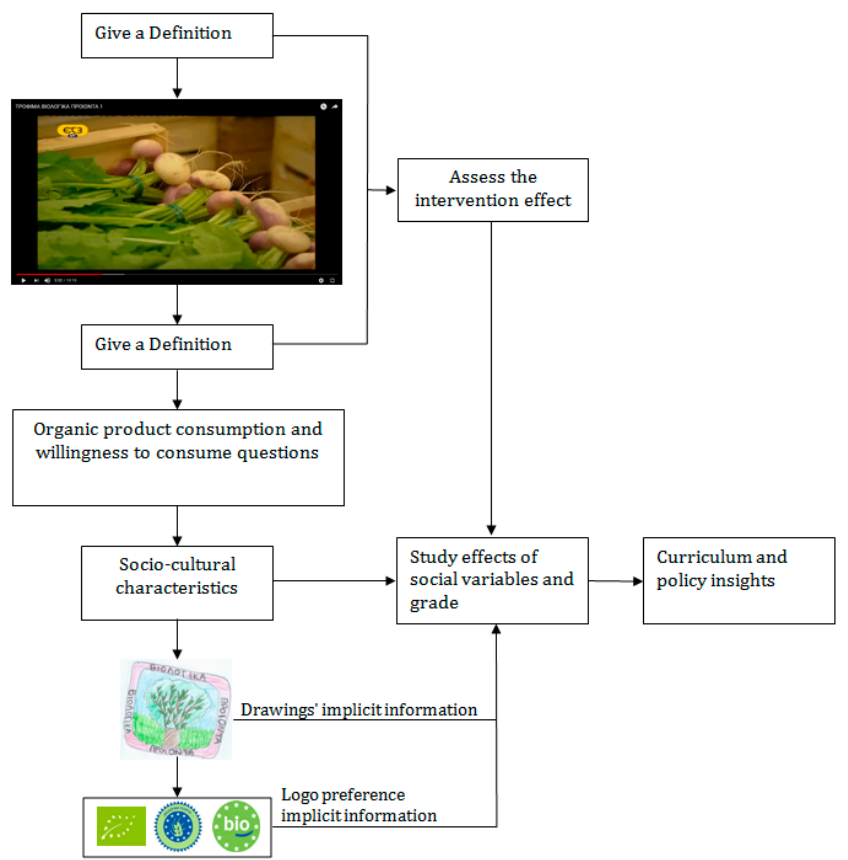

Figure 2. Flowchart of the followed procedure. Pupils give a definition of organic products, watch an information video and give a definition again. Questions about consumption with a socio-cultural analysis, drawings' information and logos' preference lead us to study effects and curriculum insights. 


\section{Results and Discussion}

This section consists of the identity of the sample, an analysis of the intervention effect, the preferred logo and the proposed dominant logo design characteristics.

\subsection{Identity of the Sample}

Seven hundred and twenty four valid questionnaires were collected from seven primary schools (Xanthi and Serres regions) in northern Greece with face-to-face in class surveys during the period of 2017-2018. The sample consisted of equal numbers of boys and girls from classes in the first to the sixth grade (i.e., aged 6 to 12 years old). Agricultural regions represented $44.5 \%$ of the sample and $55.5 \%$ was from urban regions. More specifically, our sample consisted of 351 boys and 373 girls, 109 questionnaires answered by pupils in the 1th grade, 134 in the 2th grade, 131 in the 3th grade, 113 in the 4th grade, 115 in the 5th grade and 122 in the 6 th grade. Pupils with brothers or sisters were $590(81.5 \%), 388(65.8 \%)$ of them have older ones. Regarding employment status of pupils' parents, 32 $(4.4 \%)$ fathers were unemployed and $692(95.8 \%)$ were working in the public or private sector, while $269(37.2 \%)$ mothers were unemployed and $455(62.8 \%)$ were working in the public or private sector.

\subsection{Intervention Effect}

The pupils' knowledge of organic products before and after watching the video was assessed based on the provided EU definition [11]. Before the information session, $574(79.3 \%)$ of the pupils knew nothing about organic products, $76(10.5 \%)$ reported a wrong definition with some correct elements, $21(2.9 \%)$ reported a correct definition with some incorrect elements and just $53(7.3 \%)$ reported a correct definition. These results confirm the findings of Stobbelaar et al. [30] that despite the positive attitude of young people towards organic products, their knowledge and willingness to buy are low. Regarding the source of knowledge for organic products, most pupils were informed by "the family environment" (29\%), followed by "TV/press" (21\%), school including schoolteachers and classmates $(13.7 \%)$ and from the "Internet" $(7.5 \%)$, while "other sources of information" were elicited by $0.6 \%$ of our sample. Therefore, parents seem to raise awareness of quality food at home.

Examining the relationship of the "knowledge" with other variables, we found no significant effect of having an older brother/sister at home, according to a -Whitney $\mathrm{U}$ test $(z=1.093, p=$ 0.277). Furthermore, the hypothesis that girls are more likely to give a correct definition compared to boys was found to have a weak significance according to the Mann-Whitney $\mathrm{U}$ test $(z=1.771$, $p=0.077)$. Correct responses from pupils coming from urban areas were not statistically different compared to those coming from rural areas according to the Mann-Whitney $\mathrm{U}$ test $(z=1.348, p=$ 0.178). Finally, parents' occupation was found to have no effect on the pupils' initial knowledge.

After the information session, 226 (31.2\%) of 724 participants were still not able to report a correct definition, while 129 (17.8\%) gave wrong definitions with some correct information, 105 (14.5\%) gave a correct definition that also included incorrect information and 264 (36.5\%) gave a correct definition.

To assess the intervention, we ran a Wilcoxon Signed Ranks Test to compare the respondents' definition before and after the information provided and the results showed a significantly positive effect $(z=13.875, p<0.001)$ as presented in Figure 3. 


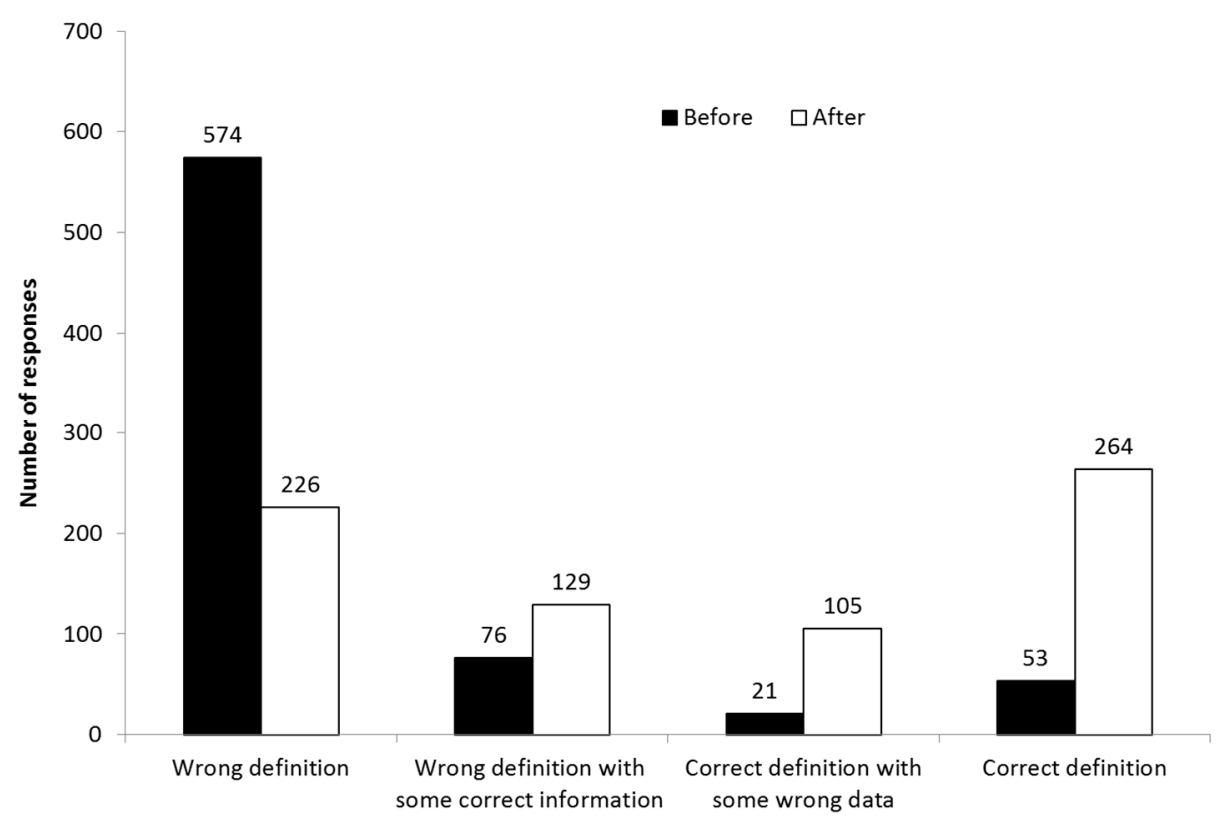

Figure 3. Responses regarding the definition of organic products before and after the information session.

After the intervention, $63 \%$ of the pupils stated their willingness to use organic products, $19 \%$ stated "probably yes", 3\% "probably no", 3\% "no" and 12\% "I do not know".

Although in general school interventions tend to have positive effects, the degree of this effect varies according to the pupils' age and grade. Initially, correct definitions are given only by pupils in the last three grades with $14 \%, 14 \%$ and $17 \%$ for grades 4,5 and 6 , respectively, while after the information session we found that the highest percentages $(59 \%)$ of correct definitions were given in the 4 th and 6th grade (Figure 4).

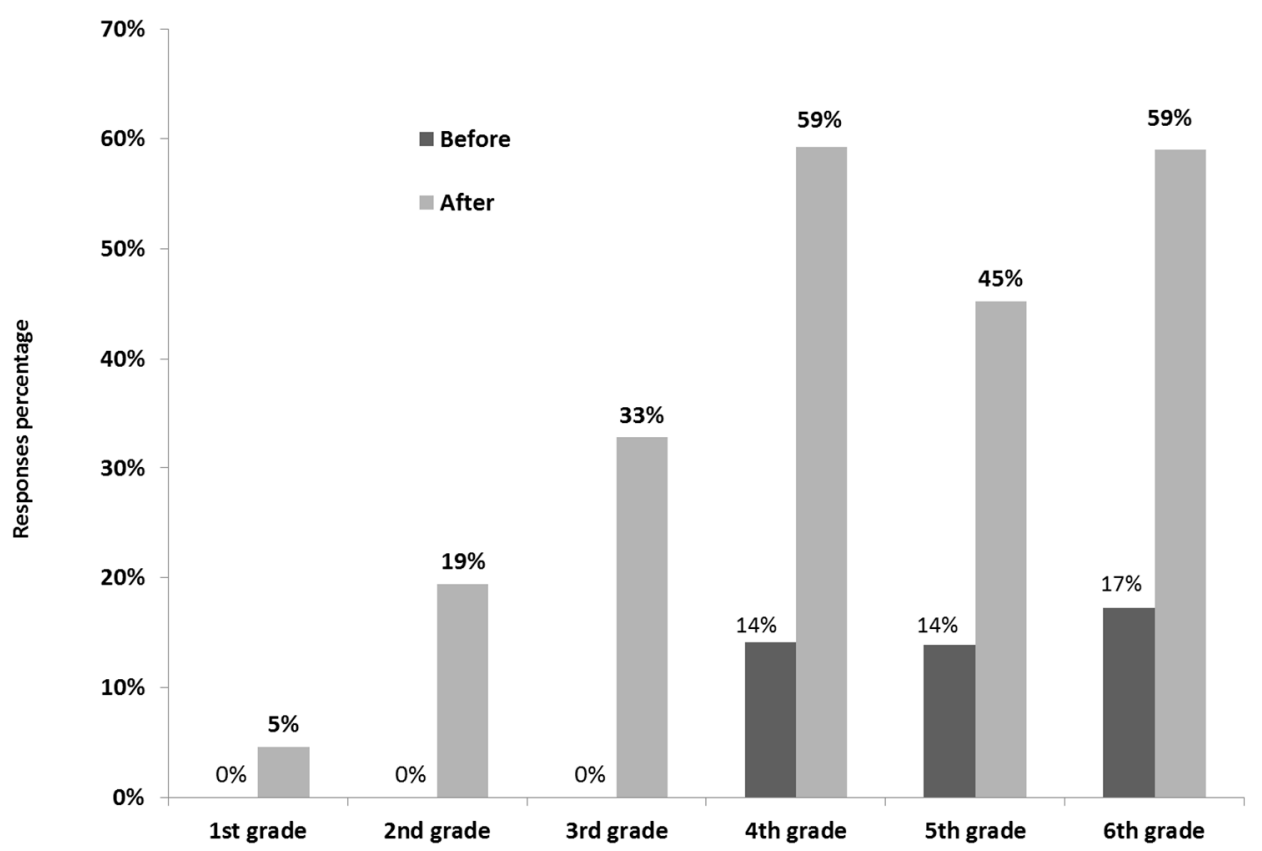

Figure 4. Correct definition percentages before and after the information session.

From the above analysis we can conclude that the appropriate age to carry out such an information session is the 4th grade onwards, where the intervention effect is higher. This complements the findings of Liefländer et al. [29] who showed that the impact of projects in connection to the environment is more sustainable if given to children younger than 11 years old. Primary school teachers of 
the focus group reached similar conclusions. They confirmed our quantitative findings, that the appropriate age to implement environmental projects is from 9 to 12 years. They stated that in the 4 th grade, the pupils more frequently ask for arguments and evidence, which introduce new concepts. Consequently, a presentation or cognitive intervention has a significant impact in this grade, while it is less pronounced in lower grades. Teachers agreed that from the 1 st to the 3rd grade the environmental issues that pupils better comprehend are related to water cycle, waste management and recycling. While a chapter about dietary habits (without specific reference to organic food/products) is first introduced in a course of the 4th grade. Therefore, pupils of this age are more receptive and ready for this kind of environmental quality issue as this is the first time they are exposed to these concepts.

The 5th grade is a transitional grade because of the introduction of several new subjects in the curriculum and in general, it is considered the most demanding grade in primary school. In addition, school teachers reported that 5 th grade pupils come into contact with many new activities and they gain more experience in learning challenges. All teachers in the focus group also agreed that the pre-puberty 5th grade pupils are more inquisitive as they do not respond so effectively to cognitive interventions, tending to lose their concentration and interest. They concluded that, because many different topics are introduced in the 5th grade, it is more difficult for the pupils to effectively absorb the new information about organic products compared to the previous and following grades.

Finally, 6th grade teachers reported that: "In 6th grade all this begins to subside. Pupils are more mature, they are preparing for secondary school and often consider themselves to be a model for younger pupils".

\subsection{Preferred Logo and Design Characteristics}

When pupils were asked to select among the past logos and the current one, $52.8 \%$ selected the old Organic Farming logo (Logo_2), 29.0\% the official European logo (Logo_1) and 18.2\% the BIO logo (Logo_3). Therefore, the logo of Organic Farming ranks first in the preferences of pupils, followed by the official EU and BIO logo. Pupils' preferences with reference to their knowledge of the organic logo definition are presented in Figure 5.

\begin{tabular}{|c|c|c|c|}
\hline & Logo_2 & Logo_1 & Logo_3 \\
\hline All pupils & $52.8 \%$ & $29.0 \%$ & $18.2 \%$ \\
\hline $\begin{array}{l}\text { Pupils who know the } \\
\text { definition }\end{array}$ & $59.3 \%$ & $24.7 \%$ & $16.0 \%$ \\
\hline
\end{tabular}

Figure 5. Percentage preference of pupils per logo.

One of the factors that may affect pupils' preference could be the text presence in Logo_3 ("Organic Farming", in Greek), as $76.6 \%$ of the drawings contained text. The words used by pupils in their logos are shown, translated from Greek, in the word cloud of Figure 6. Organic food was selected by 127 pupils (44.7\%), healthy food by 94 pupils (33.1\%), O.F., which is the abbreviation from organic food in Greek, by 41 pupils (14.4\%), vegetables by 9 pupils (3.2\%), fruits by 8 pupils (2.8\%), and healthy product by 4 pupils $(1.4 \%)$. 


\section{Vegetables \\ Healthy product \\ Food without chemicals \\ Organic Food \\ Healthy Food}

Figure 6. Word cloud of the text appearing in pupils' drawings.

Regarding the pupils' logo designs, 284 of them were selected and evaluated for further analysis. The selection criterions were the right definition given and the clearness in logo shape and synthesis. Shapes used by the pupils were $64.4 \%$ circle, $14.9 \%$ rectangle, $4.8 \%$ triangle and polygon, $3.7 \%$ diamond, $2.7 \%$ square, $0.5 \%$ trapeze and heart, and $3.7 \%$ of the drawings were without a definite geometrical shape. The colours used were those contained in the new 12 pencil box provided. The frequency of use of each colour is presented in Figure 7. The use of more than one color by each student, resulted in higher color counts compared to the number of examined drawings.

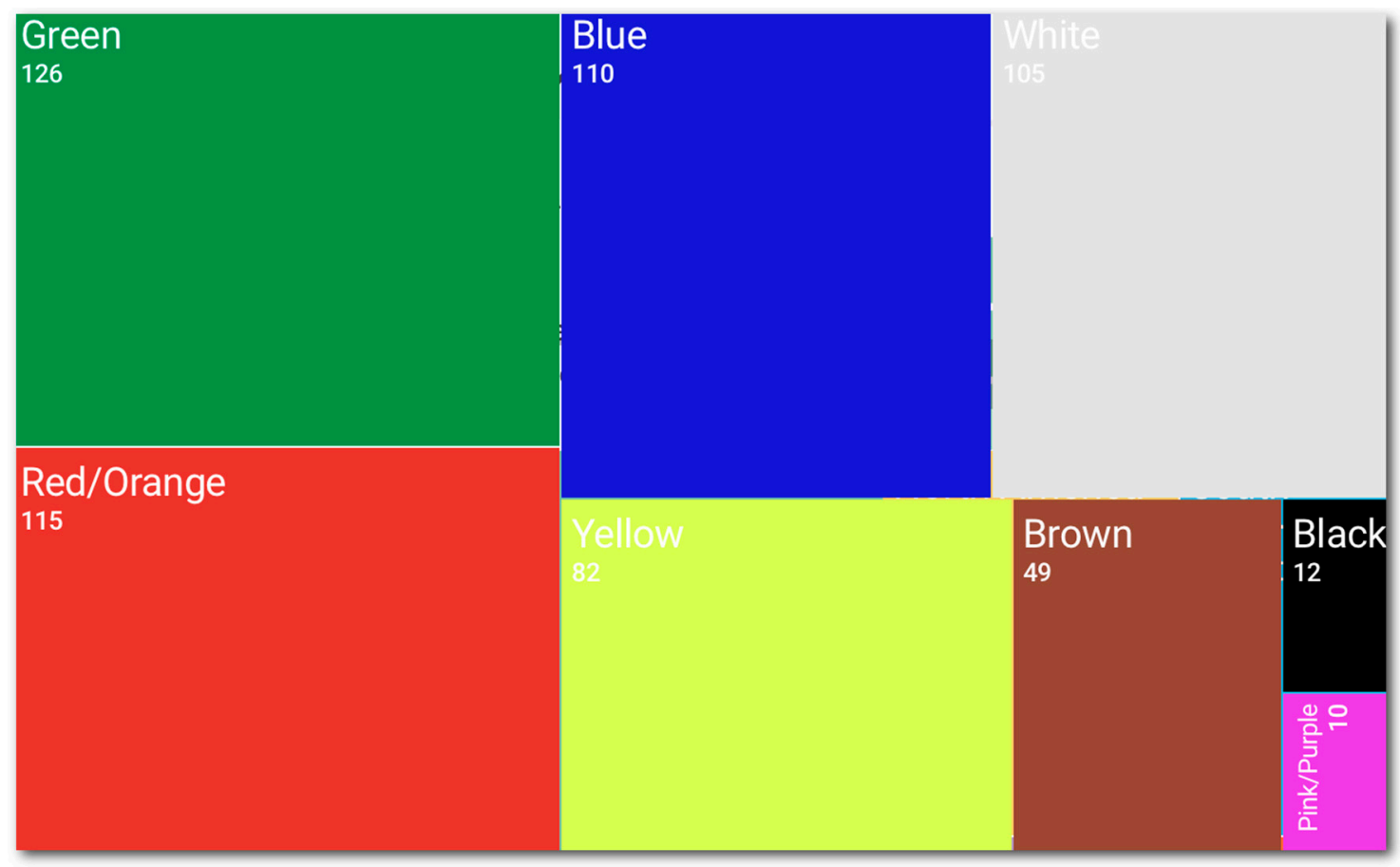

Figure 7. Treemap presenting the frequency use of each colour used for drawing an organic logo.

Pupils' drawings can represent their feelings [54], using multiple signs to implicitly reveal and externalize on paper their views and beliefs to others [55-57]. The current literature suggests that from about the age of seven, children have a set of potential strategies at their disposal in order to express psychological mood in their drawings [58]. Lines and colours are often used by children to represent their actual feelings [59]; while their selections are not made by chance [60] as pencils' point width or type of paper choices depend on mood and personality. According to the "test of the pyramids" of Pfister, as shaped by Heiss and Hiltmann [61], red, orange and yellow express an extroverted person, while green expresses a normal person. Blue and violet express the introverted and white, black and grey express the person with a strong personality [62]. Furth [63] states that the black colour causes negativity, and highlights 'dark' thoughts, fear and threat when it is used in shading. Findings reported 
by Serin [64] agree with those of Alschuler and Hattwich [65] who showed that younger children are more likely to use warm colours, while older use cold ones. As children grow, they codify colours, which is close to the actual rendering of objects. Also, the child's preference for the circular shapes is the result of the need for balance and order in their designs [66]. The combination of colours, shape and wording preference of the future consumers could be taken into account by the policy makers when they had to select the EU logo, which was chosen only on the basis of a contest among designers' logos [17]. This is evident in our study by the large percent of pupils who selected a logo different from the official logo. Given that a large number of students selected a logo different from the official one and the pupils' drawings provided new design elements, a new logo created on the basis of consumers' insights might be more effective in the organic products market.

Although our large sample was representative of all the possible socio-cultural variations, it focused only on two regions of the country. Future research could expand into more Greek regions and other countries. Another limitation was the age of the students. Our study focused on pupils in primary education (6 to 12 years old). Students of secondary education may uncover further results. In addition, our intervention was based on a full school hour, while increasing the duration could further specify our findings.

We hope to see our findings taken into consideration by education decision makers in order to incorporate quality and healthy food education into the primary school curriculum. Logo preferences and drawings are important findings for food policy strategies and can give insights into the promotion of organic products.

\section{Conclusions}

By an intervention in the primary school curriculum we showed that the majority of pupils $(79.3 \%)$ do not know what organic products are and do not intentionally use them, while just $7.3 \%$ of them reported a correct definition. According to our findings, firstly the family environment is of greatest importance, secondly the TV/Press, thirdly school and finally the Internet. The girls were slightly more likely to give a correct definition than boys and an older brother or sister in the family had no significant impact on pupils' knowledge of organic food, as well as the parents' occupation. In general, the participants in our research revealed a positive attitude towards using organic products.

Comparing pupils' responses before and after the intervention session we found significant differences, especially among pupils of 4 th grade and higher. We organized a focus teachers group and we confirmed that pupils of this age are more receptive and open to environmental issues.

This study also revealed the pupils' preference for the past logo, which indicates failures and deficiencies in the replacement of the new official logo on the market. Food policy makers should take into consideration the less informed preferences for colour, shape and text, particularly for a logo design.

Our work indicates that the education of young pupils is an essential step towards quality consumption and that similar interventions can provide significant insights into the future environmental policies.

Author Contributions: A.D.K. and K.P.T. conceived and designed the research. A.D.K. collected the data. A.D.K. and K.P.T. analyzed the data, A.D.K. and K.P.T. wrote the paper.

Funding: This research received no external funding.

Conflicts of Interest: The authors declare no conflict of interest.

\section{Appendix A}

In this appendix a photo of the colour pencils set used by the students is presented (Figure A1). 


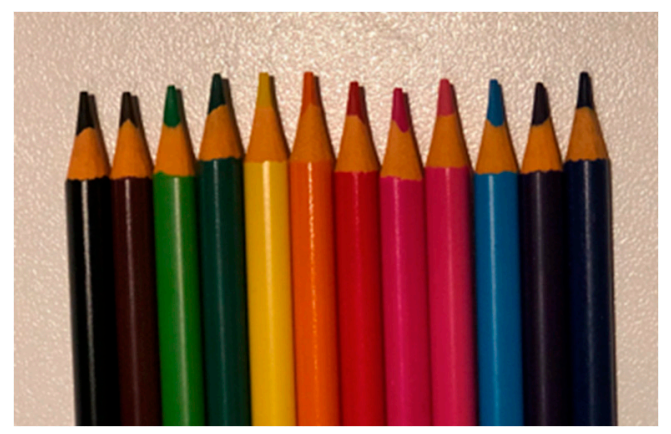

Figure A1. The 12 coloured pencils provided to the pupils.

\section{References}

1. European Commission. Special Eurobarometer 389 Europeans Attitudes towards Food Security, Food Quality and the Countryside. Available online: http://ec.europa.e (accessed on 20 June 2019).

2. Brantsæter, A.L.; Ydersbond, T.A.; Hoppin, J.A.; Haugen, M.; Meltzer, H.M. Organic Food in the Diet Exposure and Health Implications. Annu. Rev. Public Health 2017, 38, 295-313. [CrossRef] [PubMed]

3. Council Regulation (EC). No 834/2007 of 28 June 2007 on Organic Production and Labelling of Organic Products and Repealing Regulation (EEC) No 2092/91; IFOAM EU GROYP: Brussels, Belgium, 2012.

4. Colom-Gorgues, A. The Challenges of Organic Production and Marketing in Europe and Spain: Innovative Marketing for the Future with Quality and Safe Food Products. J. Int. Food Agribus. Mark. 2009, 21, 166-190. [CrossRef]

5. Eurostat. The EU's Organic Food Market: Facts and Rules (Infographic). 2016. Available online: http:/www.europarl.europa.eu/news/en/headlines/society/20180404STO00909/the-eus-organic-food-market-facts-and-rules-infographic (accessed on 28 May 2019).

6. Quah, S.; Tan, A. Consumer Purchase Decisions of Organic Food Products: An Ethnic Analysis. J. Int. Consum. Mark. 2009, 22, 47-58. [CrossRef]

7. Shafie, F.A.; Rennie, D. Consumer Perceptions towards Organic. Food Procedia Soc. Behav. Sci. 2012, 49, 360-367. [CrossRef]

8. Grzybowska-Brzezińska, M.; Grzywińska-Rapca, M.; Żuchowski, I.; Bórawski, P. Organic Food Attributes Determing Consumer Choices. Eur. Res. Stud. J. 2017, 2, 164-176.

9. McReynolds, K.; Gillan, W.; Naquin, M. An Examination of College Students' Knowledge, Perceptions, and Behaviors Regarding Organic Foods. Am. J. Health Educ. 2018, 49, 48-55. [CrossRef]

10. Gerrard, C.; Janssen, M.; Smith, L.; Hamm, U.; Padel, S. UK consumer reactions to organic certification logos. Br. Food J. 2013, 115, 727-742. [CrossRef]

11. Janssen, M.; Hamm, U. Consumer preferences and willingness-to-pay for organic certification logos: Recommendations for actors in the organic sector. In Agricultural and Food Market Faculty of Organic Agricultural Sciences; University of Kassel: Kassel, Germany, 2011.

12. Bhavsar, H.; Tegegne, F.; Baryeh, K.; Illukpitiya, P. Attitudes and Willingness to Pay More for Organic Foods by Tennessee Consumers. J. Agric. Sci. 2018, 10. [CrossRef]

13. Zepeda, L.; Chang, H.S.; Leviten-Reid, C. Organic food demand: A focus group study involving Caucasian and African-American shoppers. Agric. Hum. Values 2006, 23, 385-394. [CrossRef]

14. Janssen, M.; Hamm, U. Product labeling in the market for organic food. Consumer preferences and willingness-to-pay for different organic certification logos. Food Qual. Prefer. 2012, 25, 9-22. [CrossRef]

15. Zander, K.; Padel, S.; Zanoli, R. EU organic logo and its perception by consumers. Br. Food J. 2015, 117, 1506-1526. [CrossRef]

16. Fotopoulos, C.; Krystallis, A. Purchasing motives and profile of the Greek organic consumer: A countryside survey. Br. Food J. 2002, 104, 730-765. [CrossRef]

17. Oystein, S.; Persillet, V.; Sylvander, B. The Consumers Faithfulness and Competence in Regard to Organic Products: Comparison between France and Norway. In Proceedings of the 14th IFOAM Organic World Congress 2002, Vancouver, BC, Canada, 21-24 August 2001. 
18. Anastasiou, C.N.; Keramitsoglou, K.M.; Kalogeras, N.; Tsagkaraki, M.I.; Kalatzi, I.; Tsagarakis, K.P. Can the "Euro-Leaf" Logo Affect Consumers' Willingness-To-Buy and Willingness-To-Pay for Organic Food and Attract Consumers' Preferences? An Empirical Study in Greece. Sustainability 2017, 9, 1450. [CrossRef]

19. Kim, S.; Nayga, R.M.; Capps, O. The Effect of New Food Labeling on Nutrient Intakes: An Endogenous Switching Regression Analysis; AAEA: Nashville, TN, USA, 1999.

20. Giannakas, K. Information asymmetries and consumption decisions in organic food product markets. Can. J. Agric. Econ. 2002, 50, 35-50. [CrossRef]

21. Gotschi, E.; Vogel, S.; Lindenthal TLarcher, M. The Role of Knowledge, Social Norms, and Attitudes Toward Organic Products and Shopping Behavior: Survey Results from High School Students in Vienna. J. Environ. Educ. 2009, 41, 88-100. [CrossRef]

22. Janssen, M. Determinants of organic food purchases: Evidence from household panel data. Food Qual. Prefer. 2018, 68, 19-28. [CrossRef]

23. Vandercammen, M. Aankopen: Kinderen Beslissen; zo Gebruiken de Merken de Generationele Marketing [Purchaces: Children Decide; That Is How Brands Use Generational Marketing]; OIVO (Onderzoeks—En Informatiecentrum van de Verbruikersorganisaties): Brussel, Belgium, 2005.

24. Zografakis, N.; Menegaki, A.N.; Tsagarakis, K.P. Effective education for energy efficiency. Energy Policy 2008, 36, 3216-3222. [CrossRef]

25. Keramitsoglou, K.M.; Tsagarakis, K.P. Raising effective awareness for domestic water saving: Evidence from an environmental educational programme in Greece. Water Policy 2011, 13, 828-844. [CrossRef]

26. Michaut, A.M.K. Consumer Response to Innovative Products: With Application to Foods; Wageningen University: Wageningen, The Netherlands, 2004.

27. Riefer, A.; Hamm, U. Organic food consumption in families with juvenile children. Br. Food J. 2011, 113, 797-808. [CrossRef]

28. Gerardo, H.; Nunez, H.G.; Kovaleski, A.P.; Darnell, R.L. Formal Education Can Affect Students' Perception of Organic Produce. Hort Technol. 2014, 24, 64-70.

29. Dahm, M.J.; Samonte, A.V.; Shows, A.R. Organic foods: Do Eco-Friendly Attitudes predict Eco-Friendly behaviors? J. Am. Colleague Health 2009, 58, 195-202. [CrossRef] [PubMed]

30. Liefländer, A.; Fröhlich, G.; Bogner, F.; Schultz, P. Promoting connectedness with nature through environmental education. Environ. Educ. Res. 2013, 19, 370-384. [CrossRef]

31. Stobbelaar, D.J.; Casimir, G.; Borghuis, J.; Marks, I.; Meijer, L.; Zebeda, S. Adolescents' attitudes towards organic food: A survey of 15- to 16-year old school children. Int. J. Consum. Stud. 2007, 31, 349-356. [CrossRef]

32. Krystallis, A.; Fotopoulos, C.; Zotos, Y. Organic Consumers' Profile and Their Willingness to Pay (WTP) for Selected Organic Food Products in Greece. J. Int. Consum. Mark. 2006, 19, 81-106. [CrossRef]

33. Wijne, W.; Stienstra, S.; Buizert, N.; Borst, J. Biologisch Eigenlijk heel Logisch, of toch niet...? Hoe Denken Jongeren Erover? [Organic Actually Quite Logical, or Not ... ? How Do Young People Think about It?]; Werkstuk, Gymnasium Apeldoorn: Apeldoorn, The Netherlands, 2005.

34. Ferguson, T. 'Nature' and the 'environment' in Jamaica's primary school curriculum guides. Environ. Educ. Res. 2008, 14, 559-577. [CrossRef]

35. Rickinson, M. Learners and learning in environmental education: A critical review of the evidence. Environ. Educ. Res. 2001, 7, 207-320. [CrossRef]

36. Jenkins, E.W.; Pell, R.G. Me and the environmental challenges: A survey of English secondary school students' attitudes towards the environment. Int. J. Sci. Educ. 2006, 28, 765-780. [CrossRef]

37. Flogaitis, E.; Agelidou, E. Kindergarten teachers' conceptions about nature and the environment. Environ. Educ. Res. 2003, 9, 461-478. [CrossRef]

38. Payne, G.P. Moral spaces, the struggle for an intergenerational environmental ethics and the social ecology of families: An 'other' form of environmental education. Environ. Educ. Res. 2010, 16, 209-231. [CrossRef]

39. Martinis, A.; Kabassi, K.; Dimitriadou, C.; Karris, G. Pupils' environmental awareness of natural protected areas: The case of Zakynthos Island. Environ. Educ. Commun. 2018, 7, 106-123. [CrossRef]

40. Taber, F.; Taylor, N. Climate of concern: A search for effective strategies for teaching children about Global Warming. Int. J. Environ. Sci. Educ. 2009, 4, 97-116. 
41. Badjanova, J.; Dzintra, I.; Elga, D. Holistic Approach in Reorienting Teacher Education towards the Aim of Sustainable Education: The Case Study from the Regional University in Latvia. Procedia Soc. Behav. Sci. 2014, 116, 2931-2935. [CrossRef]

42. Official Journal of the Greek Government, 304B/13-03-03. Available online: http://www.pi-schools.gr/ download/programs/depps/fek304.pdf (accessed on 20 June 2019). (In Greek).

43. Rawcliffe, F. Practical Problem Projects; R. Compton \& Co.: Chicago, IL, USA, 1924.

44. Isaacs, S. Intellectual Growth in Young Children; G. Routledge \& Sons, Ltd.: London, UK, 1930.

45. Food Organic Products I. Video from National TV Chanel 3 (In Greek). Available online: www.youtube.com/ watch?v=1nmKjcH1Pug (accessed on 20 June 2019).

46. EU 2010. Commission Regulation (EU) No 271/2010 of 24 March 2010 amending Regulation (EC) No 889/2008 Laying down Detailed Rules for the Implementation of Council Regulation (EC) No 834/2007, as Regards the Organic Production logo of the European Union. Available online: https:/eur-lex.europa.eu/ legal-content/EN/TXT/?uri=celex:32010R0271 (accessed on 13 August 2018).

47. ECC 1991. Council Regulation (EEC) No 2092/91 of 24 June 1991 on Organic Production of Agricultural Products and Indications Referring Thereto on Agricultural Products and Foodstuffs. Available online: https://publications.europa.eu/en/publication-detail/-/publication/79cf3c57-e66f-4932-a653c45dc68e3665/language-en (accessed on 15 August 2018).

48. Bio-markt.info. The New EU Logo. 2008. Available online: http://bio-markt.info/kurzmeldungen/Das_neue_ EU_Logo.html (accessed on 15 August 2018).

49. biomanantial. The European Commission Cut the New European Bio Logo. 2008. Available online: https: //en.biomanantial.com/the-european-commission-cut-the-new-european-bio-logo-a-1045-en.html (accessed on 15 August 2018).

50. Matsagouras, H. The Interdependence in School Knowledge: Conceptual Restoration and Work Plans; Gregory: Athens, Greece, 2002.

51. Kilpatrick, W.H. The Project Method: The Use of the Purposeful Act in the Education Process. Teach. Coll. Rec. 1918, 19, 319-335.

52. Knoll, M. Project Method. In Encyclopedia of Educational Theory and Philosophy; Phillips, D.C., Ed.; Stanford University Sage: Stanford, CA, USA, 2014; Volume 2, pp. 665-669.

53. Caduto, M.J. A Guide on Environmental Values Education; UNESCO: Paris, France, 1985.

54. Barraza, L. Children's Drawings about the Environment. Environ. Educ. 1999, 5, 49-66. [CrossRef]

55. Davis, J.H. Framing Education as Art: The Octopus Has a Good Day; Teachers' College: New York, NY, USA, 2005.

56. Hall, E. The Communicative Potential of Young Children's Drawings. Ph.D. Thesis, University of Exeter, Exeter, UK, 2010.

57. Kress, G. Before Writing: Rethinking the Paths to Literacy; Routledge: London, UK, 1997.

58. Picard, D.; Brechet, C.; Baldy, R. Expressive Strategies in Drawing are Related to Age and Topic. J. Nonverbal Behav. 2007, 31, 243-257. [CrossRef]

59. Ligorio, M.B.; HSchwartz, H.N.; D'Aprile, G.; Philhour, D. Children's representations of learning through drawings. Learn. Cult. Soc. Interact. 2017, 12, 133-148. [CrossRef]

60. Farokhi, M.; Hashemi, M. The Analysis of Children's Drawings: Social, Emotional, Physical, and Psychological aspects. Procedia Soc. Behav. Sci. 2011, 30, 2219-2224. [CrossRef]

61. Heiss, R.; Hiltmann, H. Der farbpyramiden-Test nach Pfister; Huber: Bern, Switzerland, 1951.

62. Bellas, T. The Child's Sketch as a Means and Object of Research in the Hands of the Teacher; Greek Letters: Athens, Greek, 2000; pp. 132-133.

63. Furth, G. The Secret World of Drawings; Sigo Press: Boston, MA, USA, 1988.

64. Serin, Y. Figure, color, size and content relations in children's picture. Univ. Fac. Educ. J. 2003, 4, 85-98.

65. Alschuler, R.; Hattwich, L.A. Painting and Personality: A Study of Young Children; University of Chicago Press: Chicago, IL, USA, 1947.

66. Kellogg, R. Analyzing Children's Art; Mayfield: Palo Alto, CA, USA, 1969.

(C) 2019 by the authors. Licensee MDPI, Basel, Switzerland. This article is an open access article distributed under the terms and conditions of the Creative Commons Attribution (CC BY) license (http://creativecommons.org/licenses/by/4.0/). 